\title{
The Logic of the Border
}

\author{
Ioannis Trisokkas \\ Research Fellow, Institute for Advanced Study, New Europe College \\ Address: Str. Plantelor 21, 023971 Bucharest, Romania \\ E-mail: itrisokkas@nec.ro
}

\begin{abstract}
In his Science of Logic Hegel purports to give an account of a dialectical logic that generates the totality of being's fundamental structures. This totality does not exhaust the richness of being, but it exhausts the basis of this richness. Any phenomenon, whether cognitive, scientific, social or political, is based upon some or all of those structures. The paper presents and examines the logic of a structure which pervades each and every phenomenon: the border (die Grenze). It is analyzed as an advanced manifestation of "determinateness," an even more primitive structure of being, which makes explicit its intrinsic connection with not-being. What is distinctive about Hegel's analysis is that it establishes a logical character concerning the concept of "border" that precedes empirical observation and a connection with space. The aim of the paper is to reconstruct Hegel's dialectic of the border in such a way as to make this logical character apparent and convincing to contemporary audience, who begin from the assumption that all discourse about border has an empirical basis and presupposes reference to space. It will be argued that, contrary to received opinion, the very phenomenon of "border" has certain universal and necessary features which explain its very possibility, are completely a priori and are established prior to any reference to space. A discussion about "borders" that excludes any a priori investigation into this phenomenon from its domain simply fails to illuminate its most important dimension: its logical core or, if you will, its universal and necessary attributes.
\end{abstract}

Keywords: Hegel, border, logic, determinateness, self-relation, something, other, negation

The purpose of Hegel's Science of Logic, "which constitutes metaphysics proper or purely speculative philosophy" (SL 27 / WdL I 16; SL 63 / WdL I 61), is to generate the totality of the fundamental structures of being. A "fundamental structure" is necessary and, therefore, a priori. In contradistinction to Kant, Hegel takes the generation of the a priori structures of being to be an immanent, though not transcendental, deduction of these structures from the concept of pure, indeterminate being. The totality of the fundamental structures does not exhaust the richness of being, but it exhausts the basis of this richness; any phenomenon whatsoever, whether cognitive, scientific, artistic, social or political, is ultimately based upon some or all of those structures and their interrelation. To put it differently, there is no phenomenon which is not pervaded by some or all of the fundamental ontological structures.

The paper endeavours to present and examine the logic of a structure that pervades each and every phenomenon. In this case, it is the structure of the border (die Grenze) (see Enz. I 197 [\$ 92] Zusatz: "the border totally permeates everything that is there;" see also

\footnotetext{
(C) Ioannis Trisokkas, 2014

(C) Centre for Fundamental Sociology, 2014
} 
Taylor, 1975: 236 and Lakebrink, 1979: 122). It is, then, a structure which is not only necessary but also unrestrictedly universal. Hegel analyzes the border in "the logic of being," the first part of the Science of Logic, the other two being "the logic of essence," and "the logic of the concept" (on this distinction see Trisokkas, 2012: 333-334). It is analyzed as an advanced manifestation of "determinateness" (Bestimmtheit), an even more primitive structure of being, which makes its intrinsic stable connection with not-being explicit.

The concept of "border" is the dominant concept in the logic of being; it appears on almost every page after the inauguration of its defining content (SL 126 / WdL I 135). It comes into view only rarely in the logic of essence, and the logic of the concept. In the logic of being, Hegel distinguishes between the "qualitative border" (developed in the sphere of quality and exemplified mostly, but not solely, as a feature of species-species, species-genus or genus-genus relationality, or, if you will, simply as a feature of propertyrelationality) and the "quantitative border" (developed in the sphere of quantity and exemplified as a feature of magnitude and number). In the domains of nature and culture (or "spirit") which follow the domain of logic (viz. the domain of logos), the structure of the border keeps making frequent appearances, displaying itself as a fundamental ingredient of each and every natural and cultural phenomenon (for example, as a feature of bodies, communities and states).

What is idiosyncratic of Hegel's treatment of the notion of "border" is that its very first appearance as a logical structure provides the core of each and every subsequent manifestation of the border. It is exactly the presence of this structure in all subsequent forms of the border that allows us to describe them as "border." This logical core is more qualitative than quantitative (Hegel will show, surprisingly, that quantity follows from quality; see SL 111 / WdL I 118), but, still, its very essence is even more primitive than species-, genus- or property-relationality; it concerns simply the relation between something and its other.

Additionally, Hegel develops this logical core independently of spatial and temporal considerations and means it as a ground that makes even space and time possible. In his view, space and time acquire substance only in the domain of nature, which is derivative of the domain of logic (Enz. II 41-54 [\$\$254-259]). In this Hegel opposes Kant, for whom space and time, the a priori forms of intuition, are equally primordial and constitutive of knowledge as the a priori concepts (the categories) ( $\mathrm{KrV}$ A19-49 / B33-73).

The article is addressed more to researchers in the field of border studies than to Hegel scholars. Hegel studies followed a rather awry path for a long time, concentrating on the "architectonic" and "absolutist" dimensions of Hegel's project, neglecting thereby its minute details and local analyses of concepts. Recent studies, however, have changed this, with the result that such neglected concepts as "the border" have finally gotten the attention they deserve (such studies include Burbidge, 1981; Houlgate, 2006, and Winfield, 2006). The reconstruction of Hegel's analysis of the structure of the border offered in the present paper may add to the insights of those studies and help us gain an even better understanding of this structure.

As noted, the article's main concern is to convey Hegel's "logical" understanding of the border to researchers in the field of border studies. The study of borders and border 
discourse has acquired central place in the social sciences (but also, to a lesser extent, in the humanities) precisely because "borders have captured the fancy of the peoples of the world and they function as a grand motif in everyday life, everywhere" (Wilson and Donnan 2012b: 2). But while geography, history, political science, sociology and anthropology are universally considered as disciplines that can contribute to the understanding of borders (Wilson, Donnan, 2012b: 3, 5), philosophy, especially traditional, metaphysical philosophy, is almost never thought as having any usefulness to this project. There are two main reasons for this assumption. First, whereas for all the above disciplines being "rooted in space" (Wilson, Donnan, 2012b: 4) is the essential feature of borders, metaphysics, especially Hegel's, has a tendency to determine the fundamental structures of the world independently of space. For Hegel, as we will see, it is not space, place, region, territory or any other spatial dimension that fundamentally characterizes the structure of the border, but rather the qualitative (or, if you will, "logical") relation between something and its other. Second, no border discourse spoken within the limits of the aforementioned disciplines fails to include reference to the state; in fact the notion of the state is the dominant notion in border studies and determines all border discourse from the bottom up. As we will see, however, for Hegel, the most important discourse about border, the one that concerns its logical core, contains no structural use of the notion of the state (or any of its cognates: "agency," "power," "control," etc.). The present essay, then, aims at putting this unorthodox understanding of "border" on the map of border studies and thereby enhancing the latter's claim for interdisciplinarity.

The first part of the essay gives a dry, sketchy account of the development of the fundamental ontological structures from pure being to the emergence of the structure of the border. This is mandatory because Hegel's analysis of the border depends heavily upon what comes before, and, therefore, will be incomprehensible without such an account. Moreover, Hegel believes that the only criterion of the truth of an ontological structure is that it has emerged immanently from structures that came before it. Analyses that begin from empirical or common-sense or encyclopaedic (i.e. not systematic) observations quickly disintegrate into endless disputes that hide rather than disclose the phenomenon under investigation (critique of the empirical, common-sensical and encyclopaedic starting-point in both philosophical and scientific inquiry is frequent in the Hegel corpus; see especially PhdG 11-67 and WdL I 19-34, 42-43, 86-87; see also Trisokkas, 2014). This is significant because if the question "is there a single and necessary logical structure of border?" is raised, one should not give a negative answer based on the opinions or empirical investigations of the various border theorists or even the opinions of the people who live around the border (as, for example, Green (2012) does; see my remarks in the final section of the paper). The way in which the logic of the border is derived in the Science of Logic is the alpha and omega concerning its truth. What prevents this logic from being false or dogmatic is its presuppositionless derivation from pure, indeterminate being. The second part describes the logical moves that give content to the structure of the border, and culminates in the latter's separation from both "something" and "its other." In the third part, some of the themes that emerged in the second part are further illuminated, 
and particular emphasis is paid on what it means for the border to have a life of its own. I conclude with some reflections on what Hegel's logic of the border means for inquiries into this phenomenon that lie outside philosophy.

The absolute beginning of the immanent derivation of the fundamental ontological structures is sheer being (Sein), that is, "pure being, without any further determination" (SL 82 / WdL I 82), the very subject-matter of the derivation posited in its utmost generality. But sheer, indeterminate being can be thought of only as nothing (Nichts), so "being ... is in fact nothing" (SL 82 / WdL I 83). This thought of nothing is not the negative thought of the absence of being; it is rather the positive thought of absolute nothingness, sheer, indeterminate nothing (see Henrich, 1971: 88). When we are thinking of being with no determination, we end up thinking of nothing with no determination. Sheer being is sheer nothing.

The thought of sheer nothing, however, has the immediacy of being; nothing is (or, as we say, "there is nothing"). By thinking of nothing we come to think of being, because nothing is. Pure nothing, then, comes out of pure being, and pure being comes out of pure nothing. The one vanishes into the other. This constant movement of vanishing of being into nothing and of nothing into being Hegel calls becoming (Werden). Being, the subject-matter of ontological thought, has proven to be not only being and nothing, but also becoming. Being-as-becoming is the endless parade of being followed by nothing, and vice versa.

The event of becoming has certain ramifications that lead to its "sublation" (on this notion see SL 106-107 / WdL I 113-114) and the emergence of the structure of being-there (Dasein), which provides the domain in which determinateness will develop. First, by being the vanishing of being and nothing into one another, becoming entails their distinctness. Without this distinctness, there would be no becoming (SL 106 / WdL I 113; see also McTaggart, 1910: 17). Second, however, by vanishing into one another, being and nothing prove to be indistinct. If their distinctness did not vanish, they would not vanish into one another. Their vanishing simply means the cancellation of their distinctness. Third, the vanishing of the distinctness of being and nothing entails the vanishing of becoming, the vanishing of the vanishing; for without being and nothing being distinct there would be no movement from the one into the other (which is exactly what becoming is). Thus, the event of becoming has the logical consequence that (a) being and nothing are distinct, (b) being and nothing are indistinct, and (c) becoming vanishes.

This last point (c) pushes the dialectic forward, for thought is now obliged to consider the vanishing of becoming (SL 106/ WdL I 113). It is not the case that all is becoming. But what is the structure of being when the vanishing of being into nothing, and vice versa, vanishes? It surely cannot be nothing, for then becoming re-emerges. And it surely cannot be pure being, for again becoming re-emerges. But the dialectic has revealed nothing else than being, nothing and becoming - and the latter vanishes, so we are left with nothing else 
than being and nothing. We have to reflect on the cause of being and nothing generating becoming. The cause is their purity, which makes them, while being distinct, indistinct, and thereby vanish into one another. Thus, if becoming is to vanish, the purity of being and nothing has to go. The vanishing of the purity of being and nothing does not result in the vanishing of being and nothing (for this would again be becoming); it results rather in their stable unity, their settled inseparability and coexistence (SL 106 / WdL I 113). This is the only possible result of the vanishing of becoming.

Being, then, is not only sheer fleetingness. What structure does this stable unity, which Hegel calls being-there (precisely because it denotes a stable element, not because it is "in a certain place;" "the idea of space is irrelevant here" (SL 110 / WdL I 116)), necessarily exhibit? Being and nothing are inseparable from one another, but they do not vanish into one another. The "inseparability" of being and nothing is their stable connection or unity. Being is no longer pure; it is being-that-is-not-being (or simply "being that is not"). Nothing loses its purity as well; it is not-being-that-is-being (or simply "not-being that is").

The moment of "not-being" in this structure is called determinateness; thus, what makes being-there determinate (bestimmt) — to wit, an element that is not simply being, that is something more than simple being-is the not-being included in it, the not-being that is inseparable from being. In other words, exactly because of the not-being it contains, being-there is determinate being (SL 110 / WdL I 116; see also Houlgate, 2006: 298). Determinate being is "the unity of not-being with being" and "on this as ground all further determinations are developed" (SL 111 / WdL I 118; here, the phrase "all further determinations" denotes all characterizations of being beyond the simple repetition of "being" and its falling into "nothing").

Determinate being, the unity of not-being with being, is quality (Qualität) when the emphasis is on not-being (determinacy) (SL 111/ WdL I 118; see also Trisokkas, 2012: 114); it is being-that-is-not-being or, if you prefer, not-being-that-is. Simply, quality is the same as determinate being, but with the emphasis on the fact that it is determinate. When the emphasis is on being (being-that-is-not-being), determinate being is immediacy (Unmittelbarkeit). Determinate being is immediate when the emphasis is on the fact that it is instead of on the fact that it is so-and-so.

The not-being, however, which is emphasized in the structure of quality, generates a distinction in the domain of quality. This happens because it is a compound and the emphasis can be placed in either one of the two constituents; it can be not-being, but it can also be not-being. By this distinction Hegel wants to direct our attention to the fact that not-being, the quality of being, can manifest itself in such a way that the fact that it is inherently negative is hidden and what appears is only its immediate presence (SL 112 / WdL I 119-120). To use-perhaps inappropriately-an empirical example, we can think of this apple as being red without explicitly thinking that this is so because it is not green. The unity of being with not-being is affirmative quality; the unity of being with not-being is negative quality. Hegel calls affirmative quality reality (Realität) and negative quality negation (Negation) (SL 111 / WdL I 118). What the dialectic has now shown is that the 
determinateness of being is both a reality and a negation. It should be noted that this reality is distinct from determinate being; it is its reality but is not identical with it, for it contains also a negation (i.e. a negative quality, the is-not). Reality and negation are the two sides-the two constitutive moments-of determinate being's determinateness (SL 111 / WdL I 118). Being is determinate in that it is what it is (reality) and is not what it is not (negation).

The development of the dialectic demonstrates that determinate being must be something (Etwas). Reality is distinct from negation (SL 114 / WdL I 121-122), but what underlies their distinctness is one and the same structure, namely not-being (to wit, quality/ determinate being): "Reality itself . . . is determinate being. . . . Similarly, negation is determinate being..." (SL 115 / WdL I 122). Thus, the distinction between reality (not-being) and negation (not-being) is internal to determinate being (not-being); when reality negates negation in order to be what it is (i.e. an element that is not negation), what appears is not pure being or pure nothing but rather determinate being itself, and the same holds when negation negates reality. The differentiation of determinate being proves, then, to be self-relating; it starts from and returns to itself. It is a self-relation precisely because it returns to its own self after it has been differentiated: it is simplicity that is "again equal to itself” (SL 115 / WdL I 123), "a reconstituted identity," in Burbidge's words (Burbidge, 1981: 47). Determinate being is an identity-and-difference which, however, has the structure of the movement of self-relation. This exact structure of self-relating determinate being is what Hegel calls something (SL 115 / WdL I 123).

Something is a self-relating determinate being that has quality (note here that Hegel speaks of quality in general, not many qualities; the thing-with-many-qualities comes much later in the Science of Logic; see SL 484 / WdL II 129) which exhibits itself both as reality and as negation. As a reality-with-a-negation, something asserts itself as an immediate determinate being. In other words, the self-relation of something asserts itself simply as something that is. But as a reality-with-a-negation, the being-that-is-not-being, something is obliged to negate its own self, its very own self-relation; this is so because all there is at the moment is something (hence there is nothing else to be negated). The negation of something generates a not-something. But this not-something cannot be pure nothing, for this has already vanished, giving its place to determinate being. Therefore, it must be the case that the not-something which results from the negation of something is itself determinate being. Yet, as shown, determinate being is necessarily something. The negation of something, then, creates a not-something, which, however, proves to be itself something.

This move is significant because it is mediated by the negation of something. Hegel calls the not-something that emerges the other (das Andere). The other proves to be itself something; a self-relating determinate being that has quality which exhibits itself as reality and negation. But still, the other is something that is not-something (SL 116 / WdL I 124). This is the first time in the dialectic that two stable structures have emerged as distinct: something can be an other only if there are at least two somethings, to wit, two self- 
relating determinate beings. Moreover, the dialectic has proven that something comes always in par with an other; there can be no something without an other.

Something and its other stand next to one another indifferently; each relates only to itself by starting from and returning to itself (SL 116 / WdL I 125). Thus, as Houlgate (2006: 323) puts it, "negation is a constitutive moment that falls within something, but the otherness that something necessarily brings with it must form an interior sphere of its own that stands apart from something." Yet, the other is itself something, for it is selfrelating determinate being; this makes something itself an other. Thus, something is both something and other and the same holds for the other of something (SL 118 / WdL I 126).

The morale of the story is that the other is part of the identity of something, but also that there cannot be an other without something being there first (Doz, 1987: 65). Both something and its other can have an identity of their own only if they are something and stand next to one another. Reality is always the reality of a multiplicity, of something and its other.

The dialectic focuses on the something-which-is-an-other or, if you will, the otherwhich-is-something; for each something is, as seen, necessarily an other. By being an other, something makes otherness a property of its own self; it is a dimension of its identity. Something is in itself an other. This feature gives otherness an independence from the other something, in the sense that it applies not only to something else but also to the something which is its own self. As Hegel remarks, "the other ... although an other in relation to the something, is nevertheless also an other on its own account, apart from the something" (SL 118 / WdL I 126). The idea here is that otherness does not require exclusively relating something to an other something, but it can function also within one something. Something others its own self (SL 118 / WdL I 126).

This self-othering of something manifests itself in two ways. It can be the othering of something, to wit, something becoming an other of itself. But it can also be the othering of an other, which means that something becomes again its own self (i.e. that which is not an other), returning thus to itself from its being an other (Rinaldi, 1992: 148-149). This continuous process of one's becoming an other of oneself while returning to oneself Hegel calls alteration (Veränderung) (SL 118 / WdL I 127). Something is a self-relating and otherrelating determinate being which continuously alters itself and thereby "unites with its own self" (SL 118 / WdL I 127).

The determinateness-the not-being-of something has now shown itself to be the result of a threefold process; (a) the negation of the other something, (b) the negation of something itself and (c) the negation of the otherness of something itself. By negating both the other something and its own otherness, something preserves an identity (SL 119 / WdL I 127). The dialectic now focuses on something's relation to the other something, which (relation) Hegel calls being-for-other (Sein-für-Anderes). Each and every something - to wit, anything that is-necessarily has a being-for-other.

Recall, however, that something, besides having a relation with its other (i.e. its notbeing-the-other), is a self-relation. Insofar as it is a self-relation, something has no relation with its other (SL 119 / WdL I 128); they are both independent, self-enclosed, isolated 
spheres of existence. This feature of something, its very independence from its other, Hegel calls being-in-itself (Ansichsein). Being-in-itself stands in opposition to being-forother, but they are still both "moments of one and the same something" (SL 119 / WdL I 128). Being-in-itself is necessary in order for something to be something, but its being-forother is necessary for it to be determinate. This is a paradoxical structure, but it necessarily applies to something nevertheless.

Something has being-in-itself, an identity of its own, insofar as it opposes itself to its being-for-other, its relation to the other. As Hegel puts it, "insofar as something is in itself, it withdraws from otherness and being-for-other" (SL 120 / WdL I 128). This is a paradox, for something's being-for-other becomes constitutive of its identity, its beingindependent-from-the-other; without it something could not withdraw from it. Yet, the same holds in reverse; something has being-for-other insofar as it has being-in-itself, an identity of its own. For without something's being distinct from the other, the other could not be its other. As Hegel notes, being-for-other is "negative determinate being which points to being-in-itself as to its own being which is reflected into itself, just as, conversely, being-in-itself points to being-for-other" (SL 120 / WdL I 129).

Hegel, then, pace Kant, certainly thinks neither that being-in-itself has absolutely nothing to do with being-for-other, nor that it is a "lofty" philosophical notion that designates a content beyond human knowledge (SL 120-121 / WdL I 129-130). His point, rather, is that being-in-itself, the identity of something, is involved in the latter's relations to the other somethings (being-for-other) and is manifest therein. He calls this involvement of being-in-itself in something's being-for-other determination (Bestimmung), in contradistinction to determinateness (Bestimmtheit), which, as seen, is simply the general sphere of the not-being-that-is. Determination is the intrinsic character of something that is involved in something's other-relatedness, in its being-for-other; determinateness is the general domain of other-relatedness (SL 122-123 / WdL I 131-132). Determination, in other words, is only a dimension of determinateness; it is not reducible to it. Again, determination is the element which belongs to the identity of something, but at the same time is shown in its relation to its other; determinateness is simply the relation of something to an other. Houlgate (2006: 349) puts it well: "A thing's determination is not coextensive with its other-relatedness but is the being-in-itself, or identity, that a thing asserts in its relations to others (in seinem Sein-für-Anderes). The word 'in' indicates that a thing's determination informs but does not completely overlap with or exhaust its other-relatedness."

It is important to observe that something's being-in-itself contributes to something's relation to other somethings, to its being-for-other, but precisely because it does not $e x$ haust this relation, the latter must involve also elements which do not come from something's identity. Elements which influence the latter instead of being influenced by it. Since there is as yet only something and its other, the elements which contribute to something's being-for-other and do not come from something's identity must come from the other. Hegel calls this dimension of something's being-for-other something's constitution (Beschaffenheit). In Hegel's own words, "constituted in this or that way, something is in- 
volved in external influences and relationships" (SL 124 / WdL I 133). Something's beingfor-other, then, is composed of its determination and its constitution. The first designates a spontaneity, the latter a receptivity.

It has now become clear, though, that determination must alter through constitution, for the reason that they are both in a single element, namely something's determinateness (SL 124 / WdL I 133). If something's being-for-other includes also its being-in-itself (and vice versa), the former's being influenced by the other necessarily leads to the latter's being othered (see SL 124 / WdL I 134: "insofar as that which something is in itself is also present in it [i.e. in its determinateness], it is burdened with being-for-other; hence the determination is, as such, open to relationship to other;" and "the determinateness which thus holds the other within it, being united with the in-itself, brings the otherness into the latter or into the determination..."). Determination is, then, influenced by the other through its connection with being-for-other, which includes constitution, and exactly for this reason it must change, to wit, other itself. The morale of the story is that by coming to contact with the other, something exhibits its identity, but at the same time it receives elements from the other that transform this identity. Something still has a determination, but in the process of relating to the other this very same determination collapses to constitution. This is not an event that cancels determination out, leaving something only with its constitution. Something always has an identity of its own, but every time it comes to contact with its other, its identity is reconstituted. The constitution of something permeates its very core-it does not simply paint the colours of its surface (SL 125 / WdL I 134: "The constitution belongs to that which the something is in itself; something alters with its constitution").

We have learned that there is no something without an other (cf. Enz I 197 [\$ 92] Zusatz: "In something we at once hit upon the other, and we know that there is not only something, but also something else"), and that something's identity (a) exhibits itself in its relation to its other, (b) contributes to this relation and (c) is affected by this relation. As the other is also something, the same holds for it. Both something and its other have a constitution and a determination which are affected by their relation. Yet, all this "contact" of something with its other does not reach a point where the difference between them collapses; as somethings, something and its other are self-relating and thus maintain their otherness. Houlgate (2006: 356) puts it well: "Something in its ownmost being must... influence and be influenced by its other and at its heart it must not be that other." It is exactly at this point that the structure of the border makes its first appearance.

This stability of otherness ("the other remains always an other") adds to something a border. Something influences the other and is influenced by it, but this does not cancel something out. The influence passes over into the domain of something, it even alters it, but at that moment it belongs to something, not to the other. The border designates the (logical) point where the other ends. As Hegel notes, the border of something is "the 
ceasing of an other in it" (SL 126 / WdL I 135). And since the other is itself something, it has a border as well.

Hegel points out that the preservation of something holds even in the event of selfothering (SL 125-126 / WdL I 135). Something's being-in-itself negates not only the otherness of the other something, but also the otherness of one's own self; for, as seen, something is itself necessarily an other. By othering itself, something falls back into itself, which is exactly the characteristic of something (self-relation). Thus, the phrase "ceasing of an other in it" applies also to something's own otherness, i.e. the otherness that is internal, not external, to it. In short, in all alterations of itself, whether these have their source in the other or in something's own self, something preserves (erhalten) an identity (viz. its in-itself) by stopping otherness.

The border, then, is a radical negation; it is not that negation that simply generates quality, but rather it is the negation that wholly distinguishes the other, as an other, from something. It is at its border that something affirms its identity and its separation from the other. By having a border, something is able to be something else than its other. Without a border, it would become one with its other (and thereby collapse into pure being and nothing). Hegel makes this point lucidly: "[something] is posited as relating itself negatively to the other and in so doing preserving itself" (SL 126 / WdL I 135).

But, paradoxically, despite its creating a rift between something and its other, the border attaches something to its other. This is so because there is no border without the other; something by itself would not have a border and hence would be no-thing. The border exists precisely because something and other are there as distinct elements. Something needs the other in order to have an identity and it is exactly this phenomenon that substantiates the border.

Further, the border is common to something and its other; it is shared by them. The reason for this is that the border of something, which is the endpoint of something, is the starting-point of the other-but "from the other side." To put it differently, something stops at its border precisely because the other is there; and the other stops at its own border because something is there. Thus, something and its other share the border that defines and distinguishes them. Radical-negation-of-the-other and attachment-to-theother are features exhibited in/by both sides of the border. Something and its other have a border which is one.

Hegel collects these essential features of the border into a single definition:

There is a single determinateness of both [something and its other], which on the one hand is identical with the being-within-self of the somethings as negation of the negation, and on the other hand, since these negations are opposed to one another as other somethings, conjoins and equally disjoins them through their own nature, each negating the other: this determinateness is the border. (SL 126 / WdL I 135)

The border is a "single determinateness" precisely because it is shared by both something and its other and is a "single determinateness" because it covers the sphere of not-being 
(the border denotes exactly the "logical space" where something is not its other). The border has two main functions. First, it negates the simple not-being-the-other because something, by having a border, has a character of its own, a character that is independent of the other. This character is the being-within-self of something. There is a sense, then, in which the border negates even the negation of the other, precisely because there is a sense in which something has absolutely nothing to do with the other. Second, the border "conjoins and equally disjoins" something and its other. It conjoins them because without the other something cannot distinguish itself as something. In this sense, the border brings something and its other together (in Hegel's words, "there is an affirmative community of something with its other" (SL 126 / WdL I 135)). It disjoins them because the border is the point where both something and the other stop; the border creates a rift which remains uncrossed by both something and the other, as others. In this sense, the border keeps something and its other apart.

The picture of being that has now emerged is no longer one in which a multiplicity of somethings stand next to one another in a relation of indifference. Rather, the border is a sign of the existence of an interactive plane of character distinctions. It denotes relations-between-somethings that shape their very being, that is, their identity and determinateness. To put it differently, while the primitive notion of something included a being-in-itself which had the function of closing something into itself by withdrawing it from the other, something-with-a-border constructs a barrier that actively stops the other from entering its domain as an other. There is thus a greater degree of interaction with the other in the case of the bordered something than in the case of simple something. This greater interaction increases the amount of determinateness being disclosed.

The difference of something-with-a-border from simple something becomes more apparent if we distinguish between two kinds of negation, namely (a) simple negation and (b) radical negation. Simple negation is a not-being that denotes a withdrawal: something withdraws from its other and exhibits a total self-relation, an "abstract in-itself" or "the immediate identity of something with itself," as Hegel calls it (SL I 122 / WdL I 131-132). Using observation terms, we would say that what we observe is simply the thing and nothing else. The focus falls solely on something, the other being in its shadow. This simple negation is the one that characterizes a simple something. Something-with-aborder, by contrast, exhibits radical negation. The latter represents more a pushing of the other than a withdrawal. Something-with-a-border visibly denies the other entrance into its domain, and for this exact reason its in-itself is explicitly mediated (vermittelt) by the negation of its being-for-other (SL I 122 / WdL I 132). Radical negation, then, is more of a negation than simple negation and is a feature of something that stems from its having a border. As Hegel puts it, in something-with-a-border "the not-being-for-other becomes prominent" (SL 126 / WdL I 136). The difference, then, between simple negation and radical negation is one of emphasis; in radical negation the other is more explicitly present than in simple negation.

The dialectic has disclosed that the structure of the border is quite complex and ambiguous. The reason for this is that its functions are contradictory. On the one hand, it 
aspires to exclude the other and show something as being fully independent (i.e. a selfrelating being). On the other hand, it cannot do without the other, because the very character (determinateness) of something is shaped through its distinction from the other (the "not-being-the-other"). Hegel makes this point clearly in a passage where he refers to the individual. The individual denotes a structure that does not belong to the logic of being; it belongs rather to the logic of the concept, the third and final part of the Science of Logic. As a structure, though, that incorporates (or, in Hegelese, "sublates") the structure of something (i.e. the individual is also something), the individual has a border when it behaves simply as something. This is an underperformance by the individual, which is a structure characterized more by immanence, the "swallowing" of the other, than by opposition, the confrontation with the other (a detailed analysis of the concept of individual in Hegel's philosophy can be found in Trisokkas, 2012: 187-221). The passage goes as follows:

\begin{abstract}
The individual is a self-relation (Beziehung auf sich) through its setting borders at all [its] others; but these borders are thereby also borders of itself, relations to an other (Beziehungen auf Anderes), it does not have its determinate being within its own self (in ihm selbst). To be sure, the individual is more than merely an entity bounded on all sides (das nach allen Seiten beschränkte), but this more belongs to another sphere of the [Logic, i.e. to the sphere of the concept]; in the metaphysics of being, the individual is simply a determinate something, and in opposition to the independence and self-subsistence of such something, ... determinateness effectively brings into play its appearance as negation. (SL 113-114 / WdL I 121; translation modified)
\end{abstract}

The passage confirms what has been said hitherto; the individual, as something, is a selfrelation only because it stops the other at its border; but this border stops also the individual from passing over into the other. Yet, the determination of the individual requires the presence of the other, so as the individual to have the self-relation it must have; its determinate being is, then, not within the individual but rather at its contact with the other. All in all, the individual-as-something-with-a-border is a contradiction, an ambiguity; it is a self-subsistence but also an other-relatedness (a "negation").

This ambiguous nature of the structure of the border has the corollary that it creates a "logical space" which belongs and does not belong to something. Something is the border of the other and the other is the border of something, but still the border is distinct from both something and its other. The border belongs to something precisely because something is the point where the other stops being itself and enters into the domain of something else. But it does not belong to something because the other, which is the border of something, is excluded from something. As, however, the other is also something, there arises the notion of a border or borders which is/are independent of all somethings (i.e. of every-thing). Something, then, is the border, but also, paradoxically, lies outside the border. It is necessary of something to have a border, but it is also necessary of the border to have a substance and identity of its own. In the language of Horstmann and Wadley (2006), the "margins" have now become "centers." 
This is a new development in the dialectic. Something must have a border in order to be what it is, for the border is exactly that element which marks it off from the other and gives it an identity of its own. And yet, since it is shared with the other, the border must be negated by something. Thus, the border comes to light as an element which is (also) distinct from something and has a life of its own. In the third section we will examine this peculiar life of the border in more detail.

III

Something is not a bubble amidst a multiplicity of bubbles; it is influenced by its other and influences the latter in turn. This influence engenders alteration, the alteration of something's being-in-itself, its identity. Nevertheless, despite its continuous change through the other, something always remains what it is, namely itself; something always has an identity, even if that identity is altered. The border is exactly that element that allows this to happen. Something-with-a-border maintains its identity as the something that it is while it is being influenced and changed by the other. Having-a-border means stopping the other from entering, as an other, the identity of something. Crossing a border means crossing into an other's identity. As a border, something is, in Hegel's words, "the not-being of the other" (SL 126 / WdL I 136).

It is perhaps the right place to note that the structure of the border has, firstly, emerged purely a priori and, secondly, acquired a content that is prior to any reference to space (which is distinct from what we called "logical space," a purely conceptual element) (for an opposite view see Theunissen 1980: 269). The border is, as seen, an advanced manifestation of quality and the same holds for something. The dialectic shows that in the logical domain quality comes before quantity. The border, then, denotes a structure that is first and foremost qualitative (see Enz I 197 [\$92] Zusatz; Stace, 1955: 143; Harris, 1983: 103), the resistance to "othering," to the intrusion of the other-as-an-other. Of course, as the dialectic develops, there will be quantitative manifestations of the border and in the philosophy of nature the border will acquire an explicitly spatial form. The reader, however, must always keep in mind the much richer, purely qualitative inner core of the border, a core that allows it to manifest itself in diverse fields of everyday life and scientific inquiry.

The disclosure of something as a border initiates a whole series of logical moves which culminate in (a) the separation of the border from both something and its other and (b) the characterization of such a separate element. First, it is acknowledged that not only something but also its other is a border. The other thus resists the force exercised on it by something and thereby maintains its identity (while at the same time remains open to something's qualities). Something stops the other at its border, but it is also the case that the other stops something at its own border. In the same way, then, that something is "the not-being of the other," so the other is "the not-being of something" (SL 126 / WdL I 136: "But the other is itself a something ... therefore ... its border ... keeps the first something as its other apart from it, or is a not-being of that something"). 
Second, the impression that we are now talking about two borders proves to be an illusion, for there is just one border. The other stops at the border of something, but the latter also stops at the border of the other. Yet, at the point where something stops the other begins, and there where the other stops something begins. Thus, the border is one and the same; it denotes exactly the same point. This means that something both resists to othering (i.e. asserts its identity) and is affected by the resistance of the other (i.e. is stopped from intruding the other) at the same border. The border, then, appears as a rich plane of interaction; it is at the border where each something becomes what it is, but also feels the aggressive presence of the other.

Third, insofar as something and its other have proven to be the single border of each other, this border appears to be an element that rises above the singular negativities of somethings (viz. the border is no longer as something or as an other). This is so because both something and its other stop being themselves at the border; so the border is certainly not them, it has acquired an existence that is independent of them. As Hegel puts it, "[the border is] not only not-being of the other, but not-being equally of the one and of the other something, consequently of the something as such" (SL 126 / WdL I 136).

Fourth, this separate border appears not only as a "place" of interaction, but also as a highly paradoxical structure. For it is at the border where something asserts its identity, but also stops being what it is! The sphere of something and the sphere of the other determine each other's quality, but also cancel one another out. Hegel could not be any clearer: "[The border] is the mediation through which something and other each as well is, as is not" (SL 127 / WdL I 136). Note that this paradox is a necessary condition for the possibility of something. In order for it to be the determinate thing that it is, something must both have a relation with its other and stop where the other begins. This holds for everything; humans, plants, states, social groups, artifacts, imaginary objects, neurons, or quanta (Enz I 197 [\$ 92] Zusatz). Something is what it is by both finding and losing itself at the border.

Fifth, insofar as something stops being what it is at the border, its identity separates itself from the border; and the same holds for the other, which is also something. In Hegel's phrasing, "something has its being-there outside (or, as it is also put, on the inside) of its border" and "the other, too, because it is something, is outside it" (SL SL 127 / WdL I 137). In this way, the border becomes an element which is not something. It is what-lies-between-something-and-its-other, the middle ground, a Lichtung: "The border is the middle (die Mitte) between the two of them in which they cease" (SL 127 / WdL I 137). Hegel emphasizes that this in-between is beyond something and its other, a fact that places, as a consequence, something and its other beyond each other (SL 127 / WdL I 137). This adds to the paradoxical structure of the border; something has an identity precisely because it has a border, but in order to have a border it must be outside the border (SL 127 / WdL I 137). Houlgate (2006: 365) expresses this quite nicely: "The [border] thus detaches itself logically from whatever something and its other are and shows itself to be other than the two spheres of being between which it falls." 
The question is this; what logical content does the detachment of the border from something and its other produce? Since without the border something loses its contact with the other, what is lost in this instance is the determinate being of something in relation to the other. As, however, the other is also something, it loses its determinate being in relation to something. This does not mean that something and its other become pure being or pure nothing, precisely for the reason that they are now stably determined against the border itself (i.e. they do not vanish into it). Something and its other are the not-being of the border and vice versa. They both have a determinateness, then, but this is so in relation to the border, not to each other. Further, since they do not have a negative relation with one another, something and its other collapse into one determinate being, viz. something in general, or in terms of their otherness against the border, the other in general. Here is how Hegel puts it:

But further, something as it is outside the border, the something without a border, is only a determinate being in general. As such, it is not distinguished from its other; it is only determinate being and therefore has the same determination as its other; each is only a something in general, or each is an other; thus both are the same. (SL 127 / WdL I 137)

The main significance of the detachment of the border from something is that the difference between something and its other collapses. They are no longer "aggressive" against each other, but become "one" against the border. This happens when the border appears alien to both something and its other, an element that is much bigger than they are, an element that "encompasses" or "opposes" them both. It is certainly important that the border does not here mediate between somethings, but rather stands against them. There is nothing beyond the border besides itself. Every-thing there is finds itself staring at the endless abyss of the border. This is the pure infinite, the dark hole which contains nothing but itself. (By this I do not mean that the border is indeterminate; only that there is no something beyond it.) In this dimension of itself, the border can quite appropriately be called "the limit" (rather than simply "the border"); it is that which limits something as such.

Besides being the limit of something, however, the border is also its beginning; for there where something finds its end, it finds also its beginning. Hegel gives us an example from the sphere of mathematics: "The point is ... the border of the line, not merely in the sense that the line only ceases at the point, and as a determinate being is outside it; ... on the contrary, at the point the line also begins; the point is its absolute beginning" (SL 128 / WdL I 138). This is important because it shows that the border, whatever character it has, affects and moulds the determinate being of something. Even when confronted with absolute darkness, something acquires a character through this confrontation. The line is what it is and develops the way it does exactly because its border is the point and not an altogether different element (SL 128 / WdL I 138). Although spatial examples are inappropriate here, the same, one could argue, holds for, let us say, a people whose land 
is surrounded by the ocean instead of by a forest. This people will acquire a character shaped by the nature of its border.

Sixth, the relation of something to the border is equally one of non-detachment, precisely because it always holds that "the border is essentially equally the not-being of the other, and so something at the same time is through its border" (SL 126 / WdL I 136). Hegel repeats the phrase "at the same time" three times, stressing thereby that the nondetachment of the border from something is an irreducible feature of the border (and the same holds, of course, for its detachment): “. . at the same time its border is, as the ceasing of the other in it, itself only the being of the something; through the border something is what it is, and in the border it has its quality" (SL 126 / WdL I 136). What the reader must note here is that it is not only that something behaves paradoxically at its border, but also that the border itself is paradoxical. It is both detached and not-detached from something; it has and, at the same time, does not have a life of its own.

Particular attention must be paid to the fact that the independence of the border from something designates only a dimension (or "moment") of the, admittedly highly paradoxical, structure of the border. For the border, despite its independence, is still the border of something. Without something there is no border, just as without border there is no something. Hegel expresses this contradiction very clearly in his Philosophical Propaedeutic: "[Something and other] are (1) distinct from the border or from their difference which is their middle, outside of which they are something [in general]. But (2) the border belongs to them because it is their border" (PP $128[\$ 20]$ ).

Seventh, the simultaneous "detachment" and "non-detachment" of the border from something whose border it is affects how it appears to this something. Something feels "at home" at its border because it is there where its determinate identity is affirmed. But it also feels the presence of the other there, as the other has the same border with something itself. Still, something feels the danger that looms at the border because it understands that crossing the border means losing its identity and becoming an other. Finally, as the border has detached itself from something, the latter, being unaware of another something, feels the danger of losing itself completely in the border when it enters its domain; it also feels awe (Hegel calls it "unrest" (Unruhe); see SL 128 / WdL I 138) in front of an element which has no something beyond it. All these dimensions characterize, in a paradoxical fashion, how the border appears to something.

Eighth, it is the first time since the appearance of something that an element appears which explicitly is not something. Hegel's ontology is thus enriched with an altogether different type of entity; the in-between, the middle, the boundary, or what the Presocratics tried to capture by referring to the void or the ether. Until now we were talking about a universe full of somethings, as if there was nothing between them. Now we have discovered that between them lies an element, which, on the one hand, is not something, but, on the other hand, is not nothing either. One must be careful at this juncture not to apply representational or picture thinking (Vorstellung) to the idea of a "third element" (besides something and its other), which insists that "all there is must be something" (see 
Rinaldi 1992: 151). The border, as proven, is, in some of its dimensions, the not-being of something; so, it cannot be something.

At the very beginning of the dialectic of the border Hegel warns us that this structure "manifests itself ... as an entanglement (Verwicklung) and a contradiction (Widerspruch)" (SL 126 / WdL I 136). Indeed, what we have encountered is nothing but a highly paradoxical phenomenon. Yet, while we acknowledge the contradiction of the border, we do not seem able to pinpoint an "error" in what has been disclosed. In fact, it seems what we have learned is what we knew all along. In Hegel's words, the truth of the border "is everywhere before us" (allenthalben vor uns ist) (SL 85 / WdL I 86). A kind of "recollection" (Erinnerung), then, seems to have been at play in our interaction with the dialectic of the border (on the function of "recollection" in Hegel's philosophy see the essays in Ricci and Sanguinetti 2013). This should not come as a surprise, since, as noted, "the border totally permeates everything that is there" (Enz. I 197 [\$ 92] Zusatz).

Hegel believes that what has been revealed as the structure of the border is a primitive ontological structure, in the sense that it necessarily underlies each and every manifestation of border, whether this be in the social, political, biological, physiological, artistic, or any other domain of inquiry. He also believes it is a structure that characterizes being itself, not simply our thought of being. Whether we existed or not, there would be borders in the universe (as long as there is being and something); but, of course, elements that belong peculiarly to manifestations of the border in a cultural domain (such as the border of the state or of the community) would be absent in the absence of humanity.

What does Hegel's logic of the border mean for inquiries into this phenomenon that lie outside philosophy?

(1) First of all, it should make all those investigating "borders" aware that the concept of the border is not altogether "subjective" and/or "arbitrary," and that it has a logical core that is not "up for debate." Moreover, despite statements to the contrary (Wilson and Donnan 2012b: 4), border studies must take into consideration not only the fluid and changeable aspects of borders, but also their everlasting, unchangeable logical content. This logical concept of the border, exactly because it is an objective concept and has a timeless content, must be taken into consideration by every researcher of the phenomenon.

That there is a single and necessary "logic of the border" is a thesis explicitly denied by Sarah Green. Green grounds this denial in a couple of empirical observations. She notes that borders show themselves as being "capable of taking different forms in almost every respect," including "their officially intended purpose and meaning" (Green, 2012: 575). This meaning is heavily affected by "historically changing ... political and economic conditions" (Green, 2012: 575). Yet, Green is quick to point out, there are known cases of borders whose meaning has remained the same for long periods of time; as she puts it, "the long-term maintenance of particular border configurations and dynamics is com- 
mon" (Green, 2012: 576). There is, then, variability, but also permanence concerning the meaning of empirical borders. From this Green concludes that "there is little that could be inherent about their characteristics as borders" - "not even the tendency for borders to change regularly is an inherent characteristic of borders" (Green, 2012: 575). She also universalizes her conclusion, stating that "everyone is aware that no borders have yet proven to have eternal properties" (Green, 2012: 576).

Based on this variability of meaning, Green claims that historically the understanding of borders has been filtered through that aspect of meaning which has been emphasized each time. Emphasizing one aspect results in one "logic of border," while emphasizing another aspect results in another "logic of border." Thus, the variability of meaning concerning empirical borders results in the existence of a variability of "logics of border." The "Westphalian logic of border," for example, which is "a European invention dating back to the Middle Ages" (Ben Slimane, 2010: 37), "focuses strongly on binary distinctions: the qualities and character of each side being defined by its diametrically opposed difference from the other side" (Green, 2012: 577). The "Maghreb logic," in contrast, does not divide sides in this way. The edges of the Maghreb dynasties remained undetermined, for "there was no restriction on people or goods moving across their regions", and "there was no explicit, singular or coherent meaning for these peripheral regions" (Green, 2012: 578).

Green is not always consistent in her expression, as at one place she tells us that "borders always involve a form of classification and categorization of the world, because otherwise they would not be recognized as borders" (Green, 2012: 576-577, my emphasis). This, however, is certainly a slippage, as it is followed by statements such as the following: "[T] here is nothing inherent about the character or nature of borders; there is no universal 'borderness' that applies anywhere and everywhere.... [I]nstead, they are the outcome of a particular way of understanding, constructing and performing them as border" (Green, 2012: 579). And she makes the point clearly and very strongly in the following assertion: " $\mathrm{T}]$ he obvious point that borderness can be multiple, even to the extent of some people recognizing a place or a thing as a border while others do not see anything except landscape, is a crucial aspect of what could be called 'borderness dynamics"' (Green, 2012: 581).

Green's argument fails on two fronts. On the one hand, she seems to derive the thesis that the border does not have "eternal properties" and a "single logic" from the fact that authorities and "borderlanders" alike frequently change their behaviour toward a landscape that is characterized as a "border." This, however, is a category mistake, for it implies that one goes about proving or disproving a logical category ("the border") from human experience in nature. Indeed, since all nature is fundamentally characterized by change, how could the unalterable and eternal be derived from it? This is simply impossible. Such a conclusion does not have anything to do with one's empirical findings, but with the very essence of nature and the human experience in it, namely that they are driven, by definition, by change. Green's mistake reminds us of Hume's mistake, who attempted to disprove the necessary (to wit, a priori) existence of the logical category of causality in nature while basing his argument on empirical observation! 
On the other hand, Green seems to derive the thesis that the border does not have "eternal properties" and a "single logic" from the fact that empirical manifestations of "border" exhibit opposing logical characteristics. In "Westphalian logic," for example, a border denotes a sharp distinction between this and the other side of the border. In "Maghreb logic," by contrast, this distinction is blurred and the border denotes rather an open space, both an intersection and an independent region between something and its other. However, to derive from this that there is no single logic of border presupposes that no logic can contain opposing or differing logical properties. This, though, does not hold for the logical system generated in Hegel's Science of Logic. The universal category of "border," for Hegel, is a dynamic element, a logical organism that develops through the incorporation of opposing and differing properties; it is persistence rather than static instantiation (I have defended this interpretation of the Hegelian universal in Trisokkas, 2009). This has been proven also in our preceding exposition of the logic of the border. Indeed, what Green shows to be opposing properties of a border have been shown to be necessary, a priori features of a single logic of border. Thus, all different "logics" which Green conceives as arbitrarily imposing an understanding of borders actually have as their basis the single presuppositionless logic of the border. They are differentiated precisely because they emphasize one rather than another feature of this (one and only) logic.

(2) Second, by taking the logical notion of the border seriously, every researcher is obliged to pay attention to the immense complexity of the phenomenon. This will help them heed unsuspected dimensions of empirical manifestations of borders, such as the fact that while they are intrinsically linked to the identities of "things," they also have a life of their own. There is, it is true, a certain correspondence between the a priori findings of the logic of the border and the empirically-based theoretical results of border theorists. Mark Salter, for example, distinguishes between three instances of border performativity (Salter, 2011: 66); (a) formal: borders are delimited and defended, (b) practical: people, goods and ideas cross the border, and (c) popular: the meaning of borders is challenged and thereby changes. We have seen that Hegel's logic of the border contains "moments" that correspond, more or less, to these three empirical manifestations of border. First, borders are delimited and defended when the identities of something and other are at play (this is a feature of borders highlighted by Anderson, 1996). Second, people, goods and ideas cross the border when something is determined by its other, and vice versa. Third, the meaning of a border is dramatically changed whenever a different logical component of the structure of border is emphasized (this, again, is highlighted by Green, 2012: 573-576). But while these empirically-based theoretical constructions have an air of contingency and arbitrariness, Hegel's analysis shows that such logical features of the border are necessary, universal and systematically interconnected.

Reflecting a bit more on the logical feature of the border having a life of its own, we can detect an affinity between this idea and such hegemonic concepts in border studies as "border landscapes" (geography), "borderlands" (history), and "border regions" (sociology and anthropology). Through these concepts scholars attempted to grasp the content of a border that is independent of those elements which it itself distinguishes. Strassoldo 
(1982), for example, conceives life within a border region as ambivalent and torn between the distinguished sides. Baud and van Schendel (1997: 235) point out that there are cases for which it holds that borderlands have the upper hand in their relation with their states rather than vice versa. Wilson and Donnan (2012b: 9) note that borderlands "encapsulate a variety of identities, social networks and formal and informal, legal and illegal relationships which tie together people in the areas contiguous to the borderline on both of its sides" (my emphasis). Anzaldúa (1987), Alvarez (1995), Danforth (1995), Ballinger (2003), and Zartman (2010) all stress that there is a moment when people living at borders acquire a character that transgresses the character of both sides of the border. Roitman (2005: 137-146), defines the "people of the border" as a "floating population" (population flottante), precisely in order to emphasize the distinctness of their character vis-a-vis the populations occupying the sides of the border.

(3) Third, Hegel by no means wants to maintain that his philosophical analyses of the various "conceptual" manifestations of the border exhaust everything that can be said about it. Quite the contrary; his view is that anthropological, ethnographic, political, sociological, literary, historical, and other studies of "borders" enrich our knowledge of this phenomenon. The same holds for empirical case studies of particular borders, border peoples and border programmes and policies. But Hegel is adamant that studies of such kinds do not eliminate the logical concept of the border and the content it has acquired in the Science of Logic. This is a recurrent theme in Hegel's philosophy. As he shows the utmost respect to and appreciation of the non-philosophical sciences, he expects the latter to show the same degree of respect and appreciation to philosophy (on this see especially Houlgate, 2005: 115-121). And it must be admitted that researchers in contemporary border studies do not seem to include (metaphysical) philosophy in their programmatic statements concerning an interdisciplinary study of borders. Anssi Paasi, for example, writes that border studies researchers need

to reflect on our concepts of the theory rather than trying to develop a general theory of borders. This is best done in relation to other categories inherent in geography and the social sciences, such as region, place, space, territory, agency and power, to social practices such as politics, governance and economics and to cultural processes such as ethnicity or national socialisation (education). (Paasi, 2005: 670)

This statement by Paasi reflects the general sentiment of border theorists, namely that the study of borders is restricted in the domain of the social sciences and is hegemonically determined by notions such as space, state, and economy. Developing "a general theory of borders" is something to be avoided (on this see also Newman, 2006: 156). This is exactly where Hegel would disagree with Paasi and Newman, for in Hegel's opinion, a general logical theory of border, first, can be beneficial to a collective attempt to understand borders and, second, does not necessarily undermine all other empirical approaches in the field. 
Of course, there are issues of controversy here. Whereas Hegel expects empirical scientists to conduct their empirical research within conceptual frameworks determined by logical (to wit, a priori) inquiry, there are scientists (such as Green) who deny exactly this idea, to wit, that borders have a universal logic. For these researchers, real world events and real contexts provide the starting-point of any theoretical construction and not simply the instantiation of a logical structure. This is always a fundamental difference between hardcore empirical approaches and Hegel's logical project. For Hegel, case- and comparative studies of borders cannot take place unless there is already a logic of border at hand. This must be so precisely because what unites all studies and analyses, namely the very notion of "border," must have a logical core that determines its minimum meaning, and thereby the very possibility of applying it to different empirical contexts. For example, Hegel would find the early attempt in border studies to generalize from the examination of a single case of border (a "hyperborder"), such as the Mexico-US border, to a general theory of borders (see especially Martínez, 1994, but also Romero, 2008 and Almaráz, 1976: 10) unacceptable and much worse than the beginning from a logical theory of border.

(4) Finally, Hegel's logic of the border may open new pathways of research into this phenomenon. Indeed, current research seems to begin its investigation of "borders" by placing it immediately and uncritically into the horizon of space. Hegel has shown that even before we think of a border as embedded in space, we assign it a rich conceptual, purely logical content. Our manipulation of borders-in-space can never lead to the annihilation of this logical content and for precisely this reason it must always be taken into consideration whenever this phenomenon is researched.

\section{References}

Enz. I: Hegel G. W. F. (1986) Enzyklopädie der philosophischen Wissenschaften im Grundrisse, vol. I (eds. E. Moldenhauer, K. M. Michel), Frankfurt am Main: Suhrkamp

Enz. II: Hegel G. W. F. (1979) Enzyklopädie der philosophischen Wissenschaften im Grundrisse, vol. II (eds. E. Moldenhauer, K. M. Michel), Frankfurt am Maim: Suhrkamp

KrV: $\quad$ Kant I. (1998) Kritik der reinen Vernunft, Hamburg: Felix Meiner

PhdG: Hegel G. W. F. (1989) Phänomenologie des Geistes (eds. E. Moldenhauer, K. M. Michel), Frankfurt am Main: Suhrkamp

PP: $\quad$ Hegel G. W. F. (1986) The Philosophical Propaedeutic, Oxford: Blackwell

SL: $\quad$ Hegel G. W. F. (1999) Science of Logic, Amherst, New York: Humanity Books

WdL I: Hegel G. W. F. (1986) Wissenschaft der Logik I (eds. E. Moldenhauer, K. M. Michel), Frankfurt am Main: Suhrkamp

WdL II: Hegel G. W. F. (1986) Wissenschaft der Logik II (eds. E. Moldenhauer, K. M. Michel), Frankfurt am Main: Suhrkamp 
Almaráz F. D. Jr. (1976) The status of borderland studies: history. Social Science Journal, vol. 13, no 1, pp. 9-18.

Alvarez R. R. Jr. (1995) The Mexican-US border: the making of an anthropology of borderlands. Annual Review of Anthropology, vol. 24, pp. 447-470.

Anderson M. (1996) Frontiers: Territory and State Formation in the Modern World, Cambridge: Polity.

Anzaldúa G. (1987) Borderlands/La Frontera: The New Mestiza, San Francisco: Aunt Lute.

Ballinger P. (2003) History in Exile: Memory and Identity at the Borders of the Balkans, Princeton: Princeton University Press.

Baud M., van Schendel W. (1997) Toward a comparative history of borderlands. Journal of World History, vol. 8, no 2, pp. 211-242.

Ben Slimane F. (2010) Between empire and nation-state: the problem of borders in the Maghreb. Mediterranean Frontiers: Borders, Conflict and Memory in a Transnational World (eds. D. Bechev, K. Nicolaidis), London: Tauris Academic Studies, pp. 35-55.

Burbidge J. W. (1981) On Hegel's Logic, Atlantic Highlands: Humanities Press.

Danforth L. (1995) The Macedonian Conflict: Ethnic Nationalism in a Transnational World, Princeton: Princeton University Press.

Doz A. (1987) La logique de Hegel et les problems traditionnels de l'ontologie, Paris: J. Vrin.

Green S. (2012) A sense of border. A Companion to Border Studies (eds. T. M. Wilson, H. Donnan), Chichester: Wiley-Blackwell, pp. 573-592.

Harris E. E. (1983) An Interpretation of the Logic of Hegel, Lanham: University Press of America.

Henrich D. (1971) Anfang und Methode der Logik. Hegel im Kontext (ed. D. Henrich), Frankfurt am Main: Suhrkamp, pp. 73-94.

Houlgate S. (2005) An Introduction to Hegel: Freedom, Truth and History, Oxford: Blackwell.

Horstmann A., Wadley R. L. (eds.) (2006) Centering the Margin: Agency and Narrative in Southeast Asian Borderlands, Oxford: Berghahn.

Houlgate S. (2006) The Opening of Hegel's Logic: From Being to Infinity, West Lafayette: Purdue University Press.

Inwood M. (1992) A Hegel Dictionary, Oxford: Blackwell.

Lakebrink B. (1979) Kommentar zu Hegels "Logik” in seiner "Enzyklopädie von 1830, vol. I: Sein und Wesen, Freiburg, München: Karl Alber.

Martínez O. J. (1994) Border People: Life and Society in the US-Mexico Borderlands, Tuscon: University of Arizona Press.

McTaggart J. M. E. (1910) A Commentary on Hegel's Logic, Cambridge: Cambridge University Press.

Newman D. (2006) The lines that continue to separate us: borders in our "borderless" world. Progress in Human Geography, vol. 30, no 2, pp. 143-161.

Paasi A. (2005) Generations and the "development" of border studies. Geopolitics, vol. 10, no 4 , pp. 663-671. 
Ricci V., Sanguinetti F. (eds.) (2013) Hegel on Recollection: Essays on the Concept of Erinnerung in Hegel's System, Newcastle upon Tyne: Cambridge Scholars Publishing.

Rinaldi G. (1992) A History and Interpretation of the Logic of Hegel, Lewiston: The Edwin Mellen Press.

Roitman J. L. (2005) Fiscal Disobedience: An Anthropology of Economic Regulation in Central Africa, Princeton: Princeton University Press.

Romero F. (2008) Hyperborder: The Contemporary US-Mexico Border and Its Future, Princeton: Princeton Architectural Press.

Salter M. (2011) Places everyone!: studying the performativity of the border. Political Geography, vol. 30, no 2, pp. 66-67.

Stace W. T. (1955) The Philosophy of Hegel, New York: Dover Publications.

Strassoldo R. (1982) Boundaries in sociological theory: a reassessment. Cooperation and Conflict in Border Areas (eds. R. Strassoldo, G. Delli Zotti), Milan: Franco Angeli, pp. 245-271.

Taylor C. (1975) Hegel, Cambridge: Cambridge University Press.

Theunissen M. (1980) Sein und Schein: Die kritische Funktion der Hegelschen Logik, Frankfurt am Main: Suhrkamp.

Trisokkas I. (2009) The speculative logical theory of universality. The Owl of Minerva, vol. 40, no 2, pp. 141-172.

Trisokkas I. (2012) Pyrrhonian Scepticism and Hegel's Theory of Judgement: A Treatise on the Possibility of Scientific Inquiry, Leiden: Brill.

Trisokkas I. (2014) Anachronism, antiquarianism and Konstellationsforschung: a critique of Beiser. Clio: A Journal of Literature, History, and the Philosophy of History, vol. 44, no 1 (forthcoming).

Winfield D. (2006) From Concept to Objectivity: Thinking through Hegel's Subjective Logic, Burlington: Ashgate.

Wilson T. M., Donnan H. (eds.) (2012a) A Companion to Border Studies, Chichester: Wiley-Blackwell.

Wilson T. M., Donnan H. (2012b) Borders and border studies. A Companion to Border Studies (eds. T. M. Wilson, H. Donnan), Chichester: Wiley-Blackwell, pp. 1-26.

Zartman I. W. (2010) Understanding Life in the Borderlands: Boundaries in Depth and in Motion, Athens: University of Georgia Press.

\section{Логика границы}

\section{Иоаннис Трисоккас}

Научный сотрудник Института перспективных исследований Нового европейского колледжа Адрес: Str. Plantelor 21, 023971 Bucharest, Romania

E-mail: itrisokkas@nec.ro 
B «Науке логики» Гегель ставит задачу описать диалектическую логику, которая порождает тотальность фундаментальных структур бытия. Этой тотальностью не исчерпывается все богатство бытия, но ею исчерпывается то, что лежит в основании этого богатства. Любой феномен, будь то когнитивный, научный, социальный или политический, основан на некоторых или даже всех этих структурах. В статье показана и исследована логика структуры, которая предшествует любому феномену, а именно границы (die Grenze). Она понимается как проявление той «определенности», которая является еще более простой структурой бытия, что эксплицирует ее внутреннюю связь с небытием. Особенностью гегелевского анализа является то, что он обнаруживает логический характер понятия «границы», которое предшествует и эмпирическим наблюдениям, и связи границы с пространством. Задача статьи заключается в реконструкции гегелевской диалектики границы, чтобы убедительно продемонстрировать ее логический характер для современных исследователей, которые предполагают, что любой дискурс о границах имеет эмпирические основания и предполагает связь с пространством. Статья показывает, что сам феномен «границы» имеет определенные универсальные и необходимые характеристики, которые объясняют саму его возможность и являются в полной мере априорными и схватываемыми прежде любой отсылки к пространству. Обсуждение «границ», которое исключает любое априорное исследование этого феномена, таким образом, не способно прояснить его самое важное измерение: его логическое ядро или, если угодно, его универсальные и необходимые атрибуты.

Ключевые слова: Гегель, граница, логика, определенность, самосоотнесенность, нечто, другой, отрицание 